\title{
Development of a diagnostic method for neosporosis in cattle using recombinant Neospora caninum proteins
}

\author{
Jinhua Dong ${ }^{1}$, Takahiro Otsuki ${ }^{2}$, Tatsuya Kato ${ }^{2}$ and Enoch Y Park ${ }^{1,2^{*}}$
}

\begin{abstract}
Background: Neosporosis is an infectious disease primarily of cattle and dogs, caused by intracellular parasite, Neospora caninum. Neosporosis appears to be a major cause of abortion in dairy cattle worldwide and causes to huge economic loss to dairy industry.

Results: Recombinant surface associated antigen 1 (NCSAG1), NCSAG1 related sequence 2 (NcSRS2) and the dense granule antigen 2 (NcGRA2) of $\mathrm{N}$. caninum were expressed either in silkworm or in Escherichia coli and purified. The purified recombinant proteins bound to the $N$. caninum-specific antibodies in serum samples from infected cattle as revealed by an enzyme-linked immunosorbent assay (ELISA). By co-immobilizing these recombinant proteins, a novel indirect ELISA was developed for detection of neosporosis. With the use of 32 serum samples, comprising 12 positive serum samples and 20 negative serum samples, the sensitivity and specificity of the assay were found to be 91.7 and 100\%, respectively. Seventy-two serum samples from dairy farms were also tested and one was diagnosed with neosporasis with both this method and a commercial assay.

Conclusions: A diagnostic method employing recombinant proteins of $\mathrm{N}$. caninum was developed. The method showed high sensitivity and specificity. Diagnostic test with field serum samples suggested its applicability to the practical diagnosis of neosporosis.
\end{abstract}

\section{Background}

Neosporosis is an infectious disease primarily of cattle and dogs, caused by Neospora caninum. N. caninum is an obligate intracellular protozoan parasite, which was first recognized in dogs in Norway [1], and has been found to infect a wide variety of mammals such as cattle, sheep, goats, deer and horses [2-4]. Owing to the similarity of N. caninum to Toxoplasma gondii, neosporosis was misdiagnosed as $T$. gondii infection for many years [5]. Dogs are the definitive host of $N$. caninum and cattle are usually its intermediate host. Neosporosis now appears to a major cause of abortion in dairy cattle worldwide and causes to huge economic loss to dairy industry [6]. Most studies of N. caninum have been focused on infections in dairy cattle [7].

\footnotetext{
*Correspondence: acypark@ipc.shizuoka.ac.jp

'Laboratory of Biotechnology, Graduate School of Science and Technology,

Shizuoka University, 836 Ohya, Suruga-ku, Shizuoka 422-8529, Japan

${ }^{2}$ Laboratory of Biotechnology, Department of Applied Biological Chemistry,

Faculty of Agriculture, Shizuoka University, 836 Ohya, Suruga-ku, Shizuoka 422-8529, Japan
}

$N$. caninum was identified by immunohistochemistry in two aborted fetuses from Argentina in 1998 [8]. There are several developmental stages of the parasite, which differ in size and distribution. The rapidly dividing tachyzoite stage is found within many different cells of the host. Tissue cysts are found primarily in nervous tissue and the oocyst stage is in feces excreted from definitive hosts of the parasite. The main mechanism of infection is due either the reactivation of latent tissue cysts or result from the ingestion of oocysts during the gestation period. Currently, there is no effective method of control or medical treatment of neosporosis, except the use of intensive farm management practices to reduce the likelihood of infection.

$N$. caninum possesses specialized secretory organelles called rhoptries, micronemes, and dense granules. Proteins secreted from these organelles are considered to play an essential role in intracellular parasitism by this protozoan [9]. Dense granule antigens (NcGRAs) of N. caninum are major components of both the vacuoles surrounding tachyzoites

\section{Biomed Central}


and the cyst wall that surround slower-growing bradyzoites [10], and therefore NcGRAs might be promising diagnostic tools and important protective antigens. Proteins displayed on the surfaces of intracellular pathogens are believed to play critical roles in infection. The $N$. caninum surface associate antigen 1 (NcSAG1) and NcSAG1 related sequence 2 (NcSRS2) have been identified as major surface antigen proteins of $N$. caninum tachyzoites, and were demonstrated to be immune-dominant and involved in interactions between the tachyzoite and the host cell [11]. Their predominant antigenicity was also demonstrated by their recognition by antisera from Neospora-infected animals [12].

Various diagnostic methods for neosporosis have been developed. For instance, the indirect fluorescent antibody test (IFAT) was employed to detect anti- $N$. caninum antibodies in sera of cattle, to evaluate the infection status [13]. Besides IFAT, other serological diagnostic tools such as immunoblotting [14], agglutination tests [15] and enzymelinked immunosorbent assays (ELISA) [16-18] are also available. For serological evaluation of neosporosis, total proteins of the parasite or recombinant antigens are generally used. Recombinant antigens are easily produced in large quantities and can be standardized readily.

With the aims of achieving a reliable diagnosis and developing vaccines, many proteins of $N$. caninum have been studied. However, the number of recombinant proteins that have been investigated as vaccine candidates is limited. The surface protein NcSRS2, expressed in recombinant vaccinia virus, offered adequate protection against transplacental passage and was found to limit parasite dissemination [19]. Other proteins, such as NcSAG1 [20] and NcMIC3 [21] were also reported to have high antigenicity. A number of proteins from $N$. caninum have been expressed as inclusion bodies in E. coli, but proteins refolded in vitro may not have the complete original structure, resulting in limited antigenicity.

Table 1 Primers used in this study

\begin{tabular}{|c|c|}
\hline Primer name & Sequence $\left(5^{\prime}-3^{\prime}\right)$ \\
\hline GRA2SfiNcoFor & ACGGCCCAGCCGGCCATGGCCGATITTCT \\
\hline GRA2NotHisBack & TCTGCGGCCGCATTGACTTCAGCTTCT \\
\hline GRA2NotHisFor & AGTCAATGCGGCCGCGGTCGAGCACCACCA \\
\hline Sbfl-His4Back & ACATCCTGCAGGTCAGTGGTGGTGGTG \\
\hline FLAGSfiFor & GACTACAAGGATGACGATGACAAGGCGGCCCAGCCGGCCA \\
\hline SRS2SfiNcoFor & CGGCCCAGCCGGCCATGGCGCCGTTCAAGT \\
\hline SRS2NotBack & TCTGCGGCCGCGGGGGAATCGCCGTTCTCT \\
\hline CACC-bx-FLAG-HRV3C Forward & $\begin{array}{l}\text { CACCATGAAGATACTCCTTGCTATTGCATTAATGTTGTCAA } \\
\text { CAGTAATGTGGGTGTCAACAGACTACAAGGATGACGATGAC } \\
\text { AAGGGTGCACTTGAAGTCCTCTITCAG }\end{array}$ \\
\hline SAG1Forword & TATGGTACCGATCAGAAAAATCACCTCTA \\
\hline SAG1Reverse & ATAGAGCTCTCACGCGACGCCAGCCGCTAT \\
\hline
\end{tabular}

In this paper, we report the expression and purification of recombinant $N$. caninum proteins, NcGRA2, NcSRS2, and NcSAG1, as soluble proteins in E. coli or silkworms. Furthermore, a diagnostic method for neosporosis was developed using the recombinant proteins.

\section{Results}

Expression of MBP-NcGRA2, MBP-NcSRS2 and NcSAG1, and purification

The genes for NcGRA2 and NcSRS2 were amplified by polymerase chain reaction (PCR) using appropriate primers (Table 1) and cloned into a pMAL system, with which recombinant proteins could be expressed as fusion proteins with Maltose Binding Protein (MBP), as described in Figure 1A. MBP-NcGRA2 and MBPNcSRS2 were expressed as soluble forms in E. coli. The periplasmic fraction and culture supernatant were collected and purified with Talon $\mathrm{Co}^{2+}$-immobilized resin. The purified proteins were separated by sodium dodecyl sulfate-polyacrylamide gel electrophoresis (SDS-PAGE) and blotted onto polyvinylidene fluoride (PVDF) membranes for western blot. The molecular weight of the fusion protein MBP-NcGRA2 was estimated at approximately $64 \mathrm{kDa}$ (Figure 2A), which was in agreement with that deduced from its amino acid sequence. The other purified protein, MBP-NcSRS2, with an estimated molecular weight of $90 \mathrm{kDa}$, was also confirmed (Figure 2A). NcSAG1 gene was cloned into a Bacmid system and expressed in silkworms (Figure 1B). Recombinant NcSAG1 was purified as a single band at about $38 \mathrm{kDa}$ (Figure 2B), which matched its estimated molecular weight.

\section{Antigenicity of recombinant Neospora caninum proteins and optimization of assay}

To check the antigenicity of the expressed N. caninum proteins and to optimize the amount of protein used for 


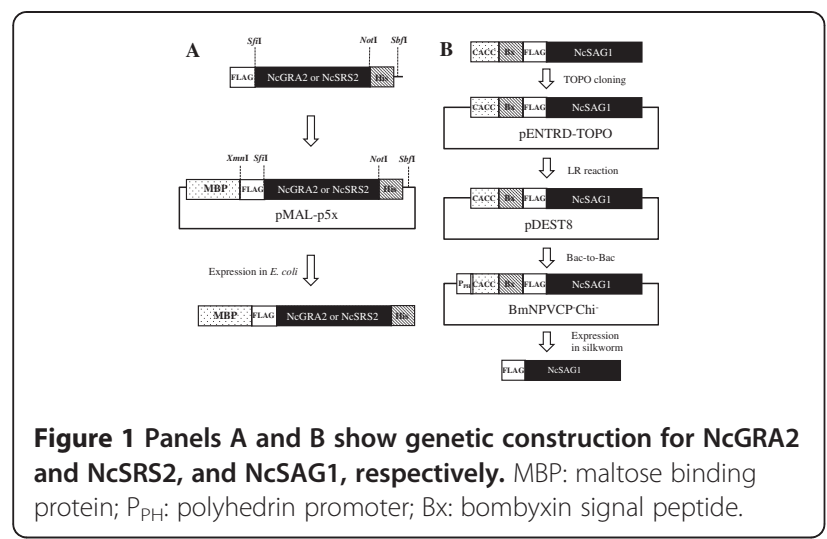

immobilization, an indirect ELISA was performed. Purified MBP-NcGRA2, MBP-NcSRS2, or NcSAG1 was diluted to final concentrations of $0.25,0.5,1.0$, and $2.0 \mu \mathrm{g} / \mathrm{ml}$, and immobilized on a microplate at $4^{\circ} \mathrm{C}$ overnight, respectively. After blocking, neosporosis-negative or -positive cattle sera were added, followed by anti-bovine antibody HRP, and detected by the addition of 3,3',5,5'-tetramethylbenzidine (TMBZ) substrate. High signal intensity was observed in the wells to which serum from neosporosis-positive cattle had been added (Figure 3). On the other hand, only a low signal was detected for neosporosis-negative samples. This demonstrates that the recombinant $N$. caninum proteins retained the properties of the native proteins of $N$. caninum, and that MBP-NcGRA2, MBP-NcSRS2, and NcSAG1 have antigenicity sufficient for immunization.

To optimize the amounts of proteins used for immobilization, each recombinant protein at $0.25,0.5,1.0$, and $2.0 \mu \mathrm{g} / \mathrm{ml}$ was analyzed. Based on the results, the percent positive value (PP value), which was defined as the ratio of the mean absorbance value of sample serum to

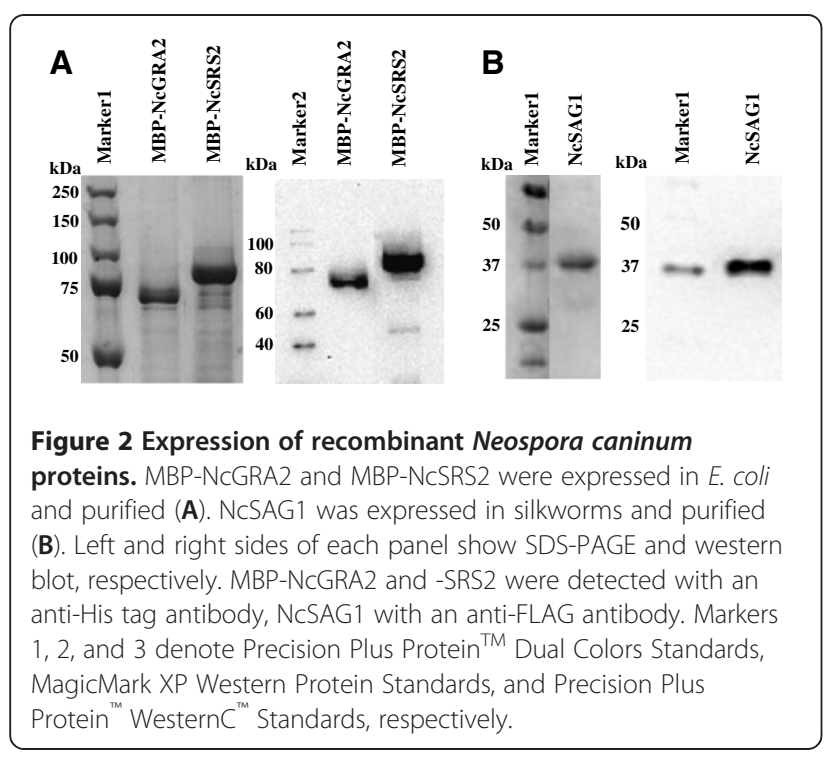

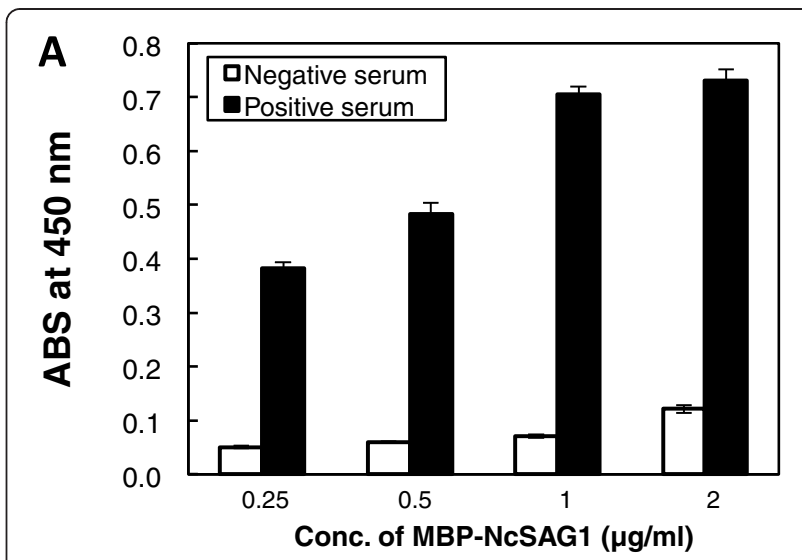
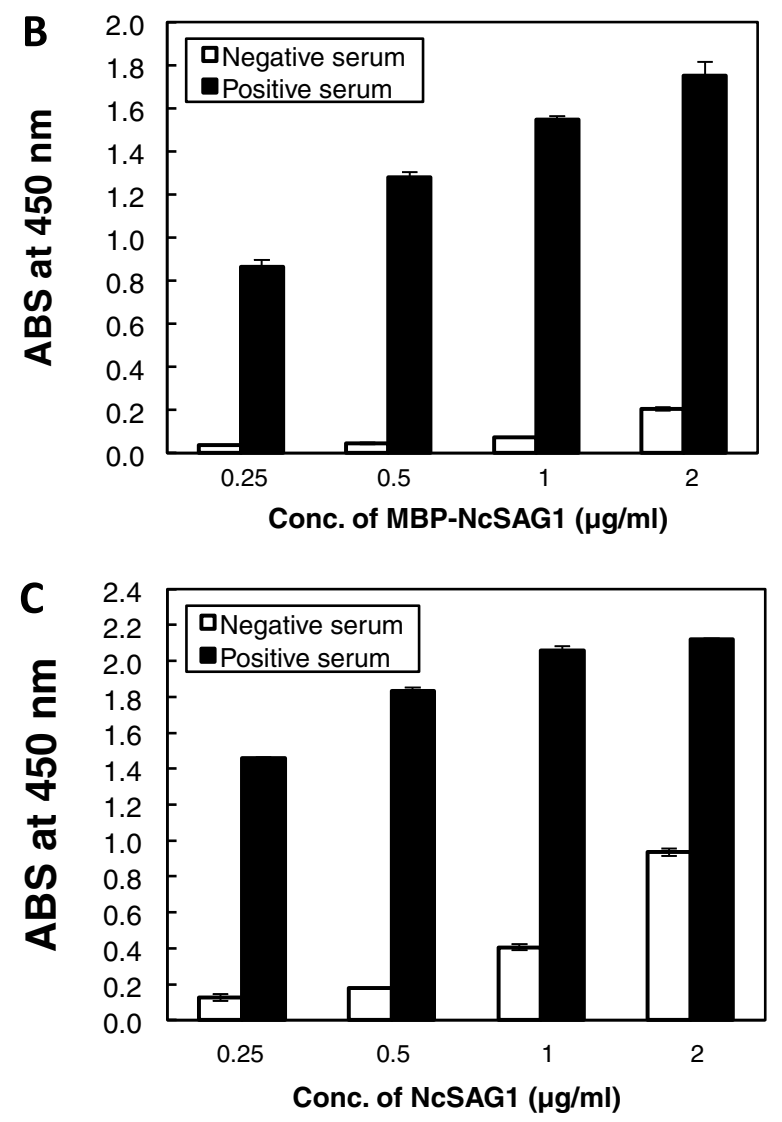

Figure 3 Optimization of recombinant Neospora caninum protein amounts for the diagnostic assay. MBP-NCGRA2 (A), MBP-NCSRS2 (B), or NCSAG1 (C) was immobilized on a 96-well microplate at concentrations of $0.25,1,0.5$, and $2 \mu \mathrm{g} / \mathrm{ml}$. ELISAs were performed to test the anti-N. caninum antibodies in negative and positive cattle serum samples $(n=3)$.

that of the positive control, as a percentage, was calculated for each concentration of protein. Concentrations at which the lowest PP values were obtained were considered to be most suitable. For MBP-NcGRA2, the PP values were $13.2,12.5,10.0$, and 16.6 at $0.25,0.5,1.0$, and $2.0 \mu \mathrm{g} /$ 
$\mathrm{ml}$, respectively, suggesting that MBP-NcGRA2 worked well at $0.25-2 \mu \mathrm{g} / \mathrm{ml}$ and the most suitable concentration should be around $1.0 \mu \mathrm{g} / \mathrm{ml}$. For MBP-NcSRS2, the PP values were 4.3, 3.5, 4.7, and 11.7. MBP-NcSRS2 worked soundly within the range of $0.25 \mu \mathrm{g} / \mathrm{ml}$ to $2 \mu \mathrm{g} / \mathrm{ml}$, and $0.5 \mu \mathrm{g} / \mathrm{ml}$ gave the lowest PP value. PP values for NcSAG1 at $0.25,0.5,1.0$, and $2.0 \mu \mathrm{g} / \mathrm{ml}$ were $8.6,9.7,19.7$, and 44.0. NcSAG1 at a lower concentration of $0.25-1 \mu \mathrm{g} / \mathrm{ml}$ is appropriate for the detection of anti- $N$. caninum antibodies in cattle serum.

We also optimized the protein concentrations for coimmobilization by a similar method, as described above. A protein cocktail solution including MBP-NcGRA2, MBP-NcSRS2, and NcSAG1 at concentrations of 1.0, 0.5 , and $0.25 \mu \mathrm{g} / \mathrm{ml}$, respectively, gave an ideal result, and was adopted as the detector for neosporosis.

\section{Evaluation of Neospora Caninum detection}

An indirect ELISA method was designed to detect bovine $N$. caninum-specific antibodies in serum with the recombinant $N$. caninum protein cocktail described above. Anti-Neospora antibodies-recombinant N. caninum proteins was formed a complex with HRP-conjugated anti-bovine antibodies. The result was observed visually, and the optical density at a wavelength of $450 \mathrm{~nm}$ was measured using a microplate reader.

Thirty-two serum samples, comprising 12 positive and 20 negative sera, were employed to evaluate the $N$. caninum detector. The samples were also tested with individual of MBP-NcGRA2, MBP-NcSRS2, NcSAG1, or a commercial $N$. caninum isocom ELISA kit (SVANOVA Biotech $\mathrm{AB}$, Boehringer Ingelheim Svanova, Uppsala, Sweden). If the PP value was smaller than 20, the cattle were determined to be negative; if it was equal to or greater than 20, the cattle were thought to be infected with $N$. caninum. As shown in Figure 4 and Table 2, among the 12 neosporosis-positive samples, 11 were distinguished and only no.7 serum sample was misclassified. None of the 20 neosporosisnegative serum samples was misclassified with the cocktail detector. On the basis of these data, the sensitivity of this assay was found to be $91.7 \%$ and the specificity $100 \%$, when compared with the commercial $N$. caninum iscom ELISA kit.

ELISAs were also carried out with single protein immobilized for the 32 serum samples. When we only immobilized MBP-NcGRA2, two serum samples, no. 6 and no. 7 serum samples were misclassified, giving a sensitivity of $83.3 \%$ (Table 2). Similar result to protein cocktail was obtained when only either MBP-NcSRS2 or NcSAG1 was immobilized, however, PP values for most serum samples were lower than immobilization of protein cocktail. Co-immobilization of three proteins

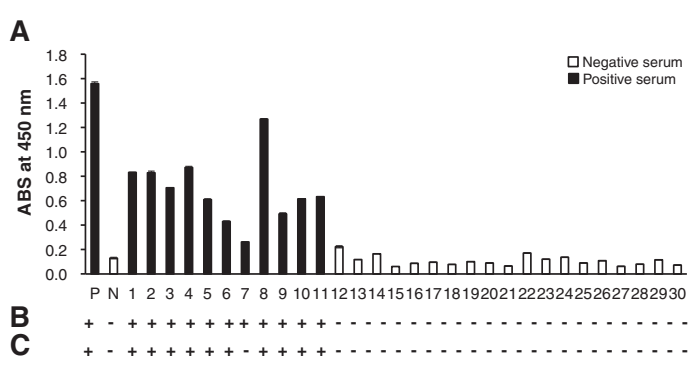

Figure 4 Evaluation of cattle serum samples with an ELISA. MBP-NcGRA2 $(1 \mu \mathrm{g} / \mathrm{ml})$, MBP-NcSRS2 $(0.5 \mu \mathrm{g} / \mathrm{ml})$, and NcSAG1 $(0.25 \mathrm{\mu g} / \mathrm{ml})$ were co-immobilized on a 96 -well microplate. Antibovine IgG-HRP was used as the secondary antibody. (A) The ELISA results with the new method developed in this study $(n=3)$. (B) Diagnostic results with a commercial ELISA kit and (c) those with this method "+"and "-" represent positive and negative results, respectively

improved the reliability of the assay with a single protein.

\section{Diagnosis of neosporosis with serum samples from dairy cattle}

Another group, comprising 72 serum samples from dairy farms in the Shizuoka Prefecture of Japan, was also tested with both the method developed in this study and the $N$. caninum iscom ELISA kit. The diagnostic results matched very well, and one serum sample was found to be positive for infection with $N$. caninum using both methods. An additional file shows this in more detail (see Additional file 1). The PP values of all the serum samples tested by the method developed in this study and by a commercial iscom ELISA kit were compared. The new method showed high values in the positive area (PP value $>20)$ in most positive samples (Figure 5).

\section{Discussion}

Neosporosis is a very common disease worldwide, and losses to livestock farms that result from neosporosisrelated abortions are a huge problem. Given that no therapy or effective vaccine is available currently, diagnosis and protection are very important to dairy farms. In this study, we developed a diagnostic method based on recombinant $N$. caninum proteins, MBP-NcGRA2, MBPNcSRS2, and NcSAG1. An ELISA with co-immobilization of those three proteins gave ideal results in both the development and validation steps. We also tried to immobilize those proteins separately; however, the results were not as good as with co-immobilization. For instance, one more positive sample was misclassified when we immobilized only MBP-NcGRA2 for use in the ELISA. Individual immobilization of MBP-NcSRS2 or NcSAG1 resulted in 
Table 2 Percent positivity values of test serum samples

\begin{tabular}{|c|c|c|c|c|c|}
\hline \multirow[b]{2}{*}{$\begin{array}{l}\text { Sample } \\
\text { number }\end{array}$} & \multicolumn{4}{|c|}{ Protein for immobilization ${ }^{*}$} & \multirow{2}{*}{$\begin{array}{c}\text { Neospora } \\
\text { caninum } \\
\text { iscomELISA } \\
\text { kit }\end{array}$} \\
\hline & $\begin{array}{c}\text { MBP- } \\
\text { NcGRA2 }\end{array}$ & $\begin{array}{c}\text { MBP- } \\
\text { NcSRS2 }\end{array}$ & NcSAG1 & $\begin{array}{c}\text { Co- } \\
\text { immobilization }\end{array}$ & \\
\hline Positive & 100 & 100 & 100 & 100 & 100 \\
\hline Negative & 10.0 & 3.5 & 10.1 & 8.3 & 5.3 \\
\hline 1 & 56.5 & 48.3 & 51.5 & 53.4 & 27.6 \\
\hline 2 & 47.3 & 52.5 & 58.2 & 53.2 & 30.0 \\
\hline 3 & 57.0 & 43.2 & 22.4 & 45.3 & 27.6 \\
\hline 4 & 59.3 & 37.8 & 51.0 & 56.0 & 39.0 \\
\hline 5 & 36.0 & 29.5 & 53.1 & 39.1 & 41.7 \\
\hline 6 & 19.0 & 21.2 & 28.8 & 27.6 & 35.9 \\
\hline 7 & 18.5 & 13.0 & 14.8 & 16.8 & 20.5 \\
\hline 8 & 92.1 & 73.0 & 78.3 & 81.4 & 56.6 \\
\hline 9 & 45.2 & 22.5 & 30.2 & 31.5 & 26.8 \\
\hline 10 & 45.6 & 42.1 & 37.8 & 39.5 & 50.1 \\
\hline 11 & 53.2 & 36.8 & 27.2 & 40.6 & 38.4 \\
\hline 12 & 15.3 & 12.3 & 10.2 & 14.3 & 4.1 \\
\hline 13 & 10.0 & 3.4 & 5.3 & 7.6 & 6.2 \\
\hline 14 & 12.3 & 4.8 & 11.8 & 10.6 & 17.5 \\
\hline 15 & 4.1 & 5.7 & 2.4 & 3.9 & 6.3 \\
\hline 16 & 7.3 & 4.2 & 5.6 & 5.6 & 10.3 \\
\hline 17 & 4.3 & 5.0 & 8.3 & 6.2 & 2.3 \\
\hline 18 & 5.6 & 4.1 & 5.2 & 5.0 & 3.0 \\
\hline 19 & 5.3 & 4.8 & 7.2 & 6.5 & 5.3 \\
\hline 20 & 7.1 & 3.7 & 4.4 & 5.8 & 3.2 \\
\hline 21 & 3.2 & 2.5 & 6.5 & 4.2 & 2.1 \\
\hline 22 & 13.3 & 9.0 & 8.9 & 11.0 & 2.4 \\
\hline 23 & 9.5 & 6.4 & 8.2 & 7.8 & 2.9 \\
\hline 24 & 6.6 & 10.2 & 8.1 & 8.8 & 2.1 \\
\hline 25 & 4.5 & 11.4 & 4.7 & 5.8 & 3.3 \\
\hline 26 & 5.1 & 8.3 & 6.0 & 7.0 & 2.7 \\
\hline 27 & 5.2 & 4.7 & 3.8 & 4.0 & 3.0 \\
\hline 28 & 8.0 & 4.3 & 4.8 & 5.1 & 3.4 \\
\hline 29 & 9.3 & 5.9 & 7.3 & 7.4 & 3.6 \\
\hline 30 & 6.2 & 3.6 & 4.2 & 4.7 & 4.7 \\
\hline
\end{tabular}

"The concentrations of MBP-NcGRA2, MBP-NCSRS2 and NcSAG1 were 1.0, 0.5, and $0.25 \mu \mathrm{g} / \mathrm{ml}$ for both individual and co-immobilization.

lower PP values for positive serum samples than coimmobilization of three proteins.

Other proteins, such as NcMIC1 [22], NcMIC3 [21], and GRA7 [23] have also been reported to have antigenicity. Therefore addition of those proteins to the diagnostic test might increase the sensitivity of the assay. In addition, some assays use inactivated total proteins of the parasite

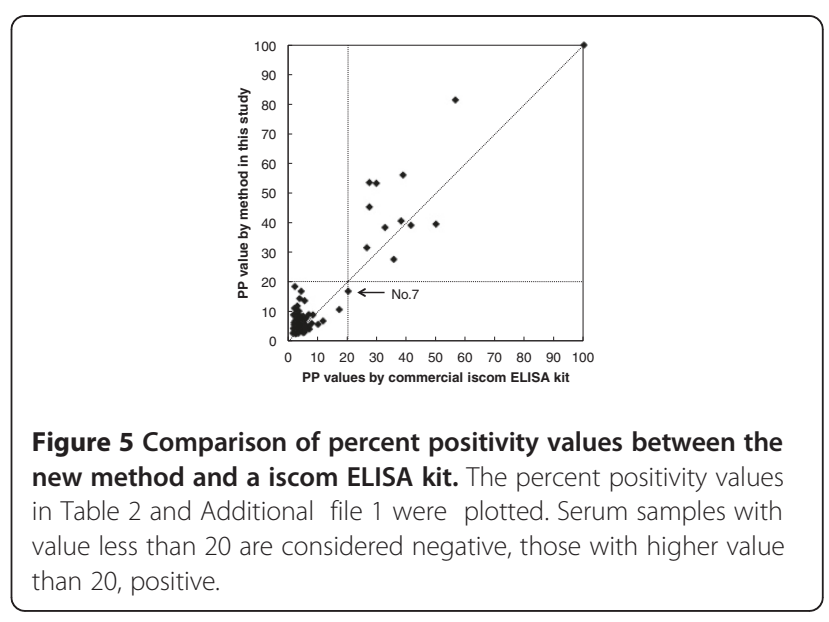

as a detector for the diagnosis of neosporosis. However, given that some proteins of $N$. caninum have high similarity to those of $T$. gondii [5], total proteins of parasites might result in misclassification. NcGRA2, NcSRS2 and NcSAG1 have identities of $33 \%, 43 \%$ and $51 \%$ to those of T. gondii, respectively. According to the report of Nishikawa et al. [24], no cross-reaction was observed between NcSRS2 and that of T. gondii. Therefore, they could be used to distinguish these two infectious diseases.

Two proteins were expressed in an E. coli protein expression system, which is a cost-effective method of producing large quantities of high-quality recombinant proteins [25]. However, this approach is often insufficient for soluble expression of recombinant proteins. The Structural Genomics Center has estimated that up to $50 \%$ of all prokaryotic proteins are insoluble when expressed in E. coli [26]. So far, many proteins of $N$. caninum have been expressed in E. coli, and most of them were expressed as inclusion bodies [27]. In this case, refolding procedures are necessary in order to obtain biofunctional proteins. Although some proteins recover their activity after refolding treatments, it is still difficult to reproduce the complete properties of the native protein.

We expressed soluble NcGRA2 and NcSRS2 by fusing them with MBP, which is capable of functioning as a general molecular chaperone in the context of a fusion protein [28]. Moreover, MBP did not hinder the immunoassay used in this study, which suggests that it may aid the production of protein on a large scale. We also tried to express NcSAG1, but unfortunately we could not obtain a soluble fraction. However, use of the BmNPV bacmid expression system, with both the cysteine-protease and chitinase genes deleted (BmNPV-CP- ${ }^{-}-\mathrm{Chi}^{-}$), led to successful expression of NcSAG1 in silkworm larvae as a soluble fraction, with less protein degradation. The viral 
protease and chitinase activities in the hemolymph of the silkworm larvae were reduced by 95 and $50 \%$, respectively [29].

Given that the tachyzoite is a very infectious stage of $N$. caninum, many studies of vaccination and detection have been focused on this stage. NcGRA2 is usually contained in dense granules, and it is highly expressed in culture-derived tachyzoites, therefore it has been studied as a potential vaccine candidate. However, so far there has been no study on the diagnosis of neosporosis that has used this protein as a detector. In this study, this protein bound to $N$. caninum-specific antibodies in serum samples from cattle, which suggests that NcGRA2 is a good candidate protein for use in diagnostic assays. The combination of NcGRA2, NcSRS2, and NcSAG1 resulted in reliable detection of neosporosis.

The new method showed high values in the positive area in most positive samples than a commercial iscom ELISA kit, which suggests that this method may show a higher level of response to anti Neospora antibodies than the commercial ELISA kit. Among the 104 samples tested, only one positive sample, no.7 serum sample, was misclassified as negative using our method (Additional file 1 and Figure 4). However, the PP value of this sample calculated with the commercial ELISA kit was 20.5, which was very close to the boundary value for interpretation; that obtained with our method was 16.8 .

In addition to cattle, naturally occurring neonatal or fetal infections caused by Neospora-like protozoa have been described in dogs, goats [30], horses [31,32], and sheep [3]. Therefore, this diagnostic method may have wide applicability to other animal species.

\section{Conclusions}

A diagnostic method employing recombinant proteins of $N$. caninum was developed. The method showed high sensitivity and specificity, suggesting its applicability to the practical diagnosis of neosporosis.

\section{Methods}

\section{Materials}

Genomic DNA of N. caninum NC-1 strain (ATCC no.50843) was purchased from ATCC (USA). The plasmid pMAL-p5x was obtained from New England Biolabs (NEB; Ipswich, MA, USA). The E. coli strains used in this study were DH5 $\alpha$ (Agilent Technologies, La Jolla, CA, USA) for general cloning and BL21 (DE3) (Novagen, Madison, WI, USA) for protein expression. The plasmids pENTR/DTOPO and pDEST8 were purchased from Invitrogen (San Diego, CA, USA). Restriction and modification enzymes were purchased from Takara-Bio (Shiga, Japan), Toyobo (Osaka, Japan), Roche Diagnostics (Tokyo, Japan) or NEB. Oligonucleotides were synthesized either by Operon (Tokyo, Japan) or Invitrogen (Tokyo, Japan). Other chemicals, reagents and antibodies, unless otherwise indicated, were obtained from Sigma (St Louis, MO, USA) or Wako Pure Chem. (Osaka, Japan). Cattle serum samples for the diagnosis of neosporosis were provided by Shizuoka Prefecture Tobu Livestock Disease Diagnostic Center (101 Nitta Kannamicho Tagata-gun, Shizuoka Prefecture, Japan). The commercial N. caninum iscom ELISA kit, used as a reference, was purchased from SVANOVA Biotech AB (SVANOVA Biotech AB, Boehringer Ingelheim Svanova, Uppsala, Sweden).

\section{Construction of pMAL-p5x-NcGRA2 and pMAL-p5x- NcSRS2}

The NcGRA2gene without its original signal peptide was amplified by polymerase chain reaction (PCR) using the primer pair GRA2SfiNcoFor/GRA2NotHisBack from the plasmid pET-NcGRA2, which was constructed previously by our group. His tag DNA was amplified from a pET52b (+) plasmid with primers GRA2NotHisFor and SbfI-His4Back. The NcGRA2 and His tag genes were linked by splicing overlap PCR. FLAG tag was attached to the NcGRA2 gene by PCR with the primers FLAGSfiFor and SbfI-His4Back. The amplified DNA was purified with an Illustra ${ }^{\mathrm{TM}}$ GFX $^{\mathrm{TM}}$ PCR DNA and Gel Band Purification kit (GE Healthcare), followed by digestion with $S b f 1$ and cloning into a predigested pMAL-p5x vector with $X m n \mathrm{I} / S b f \mathrm{l}$ to construct the expression plasmid pMAL-p5x-NcGRA2. The NcSRS2 gene without the signal peptide gene was amplified from plasmid pET-NcSRS2 with primers SRS2SfiNcoFor and SRS2NotBack, followed by purification and digestion with SfiI/NotI. It was cloned into Sfil/ NotI-digested pMAL- p5x-NcGRA2 to construct pMAL$\mathrm{p} 5 \mathrm{x}$-NcSRS2 (Figure 1A). The sequences of the primers used in this study are shown in Table 1. E. coli DH5 $\alpha$ was transformed with pMAL-p5x -NcGRA2 or pMAL-p5xNcSRS2, and cultured to yield plasmid DNA. The sequences of the genes inserted in the expression vectors were confirmed on a CEQ 8000 sequencer (Beckman Coulter, Carlsbad, CA, USA).

\section{Construction of rBmNPV-NcSAG1 bacmid}

The full-length NcSAG1 gene was amplified from pET-SAG1 by PCR using SAG1Forward and SAG1Reverse primers (Table 1). For TOPO cloning and expression in silkworms, CACC, bombyxin (bx) signal peptide, the FLAG tag sequence and a protease cleavage site, HRV3C, were attached by PCR using primers CACC-bx-FLAG -HRV3CForward and SAG1Reverse. The amplified gene was inserted into pENTR/DTOPO (Invitrogen) by the topoisomerase reaction. Using this plasmid, the full-length NcSAG1 gene was inserted into pDEST8 using Gateway technology 
(Invitrogen) to construct pDEST-NcSAG1, which was then used to transform E. coli BmDH10Bac $C P^{-} C h i^{-}$ [29]. Blue-white selection was performed to identify colonies that contained the recombinant bacmid. Recombinant Bombyx mori nucleopolyhedrovirus (rBmNPV-NcSAG1) bacmids were extracted from white transformants and insertion of the NcSAG1 gene was confirmed by PCR.

\section{Expression of MBP-NcGRA2 and MBP-NcSRS2, and purification}

E. coli BL21(DE3) cells were transformed with pMALp5x-NcGRA2 or pMAL-p5x-NcSRS2, grown on LuriaBertani (LB) medium agar plates containing $100 \mu \mathrm{g} / \mathrm{ml}$ ampicillin (LBA) at $37^{\circ} \mathrm{C}$ for $16 \mathrm{~h}$. A single colony was cultured in LBA medium at $37^{\circ} \mathrm{C}$ with shaking at $200 \mathrm{rpm}$ overnight, and inoculated subsequently into 1 liter of LBA medium. When the $E$. coli cells had multiplied to $2-4 \times 10^{8}$ cells $/ \mathrm{ml}\left(\mathrm{A}_{600} \sim 0.5\right), 0.3 \mathrm{mM}$ of isopropyl- $\beta$-d-galactopyranoside (IPTG) was added, and the culture was incubated further at $30^{\circ} \mathrm{C}$ for $8 \mathrm{~h}$. The E. coli cells were harvested by centrifugation at $4000 \times \mathrm{g}$ for $20 \mathrm{~min}$ at $4^{\circ} \mathrm{C}$. The periplasmic fraction was extracted according to the protocol provided by NEB. Supernatant of culture was also collected and precipitated by adding ammonium sulphate at a final concentration of $75 \%(\mathrm{w} / \mathrm{w})$. His-tagged MBP-NcGRA2 and MBP-NcSRS2 were purified from the periplasmic fraction and concentrated supernatant with Talon $\mathrm{Co}^{2+}$-immobilized resin (Clontech, Takara-Bio) according to the instructions provided by the manufacturer. The purified proteins were analyzed by SDS-PAGE and western blot.

\section{Expression of NcSAG1 in silkworms and purification}

NcSAG1 was expressed in silkworms. The recombinant bacmid containing the NcSAG1 gene $(10 \mu \mathrm{g})$ was mixed with one-tenth volume of DMRIE-C (Invitrogen) and incubated at room temperature for over $45 \mathrm{~min}$. Fifty microliters of this mixture was injected into a silkworm larva on the first day of the fifth instar larvae (Ehime Sansyu Co. Ltd., Ehime, Japan). Injected silkworm larvae were reared for 5-7 days, and the hemolymph collected was centrifuged to remove hemocytes at $2400 \times \mathrm{g}$ for $10 \mathrm{~min}$ at $4^{\circ} \mathrm{C}$. The supernatant was used as a hemolymph sample for purification. NcSAG1 was purified with an ANTIFLAG M2 Affinity Gel (Sigma) according to the instructions provided by the manufacturer.

\section{SDS-PAGE and western blot}

The expressed MBP-NcGRA2, MBP-NcSRS2, and NcSAG1 were analyzed by SDS-PAGE as described by Laemmli [33], and by western blot. Ten microliters of the protein samples were separated by SDS-PAGE and blotted onto a PVDF (Bio-Rad). After blocking the membrane with phosphate-buffered saline (PBS: $\mathrm{KH}_{2} \mathrm{PO}_{4}, 1.47 \mathrm{mM} ; \mathrm{Na}_{2} \mathrm{HPO}_{4}, 8.10 \mathrm{mM} ; \mathrm{NaCl}$, $136.89 \mathrm{mM} ; \mathrm{KCl}, 2.68 \mathrm{mM}$ ) containing $2 \%$ skimmed milk (MPBS) at room temperature for $2 \mathrm{~h}, 1 \mu \mathrm{g} / \mathrm{ml}$ of anti-His antibody (for detection of MBP-NcGRA2 and MBP-NcSRS2) or anti-FLAG antibody (for NcSAG1) was added to the membrane in an appropriate volume. After incubation for $1 \mathrm{~h}$, the membrane was washed with PBST (PBS containing 0.1\% Tween 20) three times, and anti-mouse IgG HRP conjugate (Promega, Madison, WI) was poured on prior to incubation for $1 \mathrm{~h}$. After washing with PBST three times, the bands were developed with ECL Plus reagents (GE Healthcare) and detected with a VersaDoc Imaging System (Bio-Rad).

\section{Indirect ELISA}

An indirect ELISA was performed to investigate the antigenicity of recombinant proteins and diagnose neosporosis. Each well of a microplate was coated with $100 \mu \mathrm{l} /$ well of recombinant protein in PBS overnight at $4^{\circ} \mathrm{C}$. After blocking with $200 \mu \mathrm{l}$ of MPBS, $100 \mu \mathrm{l}$ of serum samples from $N$. caninum-infected cattle or healthy cattle, diluted 1000-fold in MPBS, were added and the plates incubated for $1 \mathrm{~h}$ at $25^{\circ} \mathrm{C}$. Each well was washed three times with PBST, and incubated with $100 \mu \mathrm{l} /$ well of 5000 -fold diluted HRP/ anti-bovine antibody conjugate in MPBS. Anti-N. caninum antibodies bound to recombinant proteins were detected by the addition of TMBZ solution.

\section{Optimization of diagnostic assay}

To optimize the immobilization of recombinant $N$. caninum proteins, series diluted proteins were immobilized for indirect ELISA. Based on the results of the ELISA, the PP value was calculated for each concentration of protein. After the optimum concentrations of MBP-NcGRA2, MBP-NcSRS2, and NcSAG1 had been decided, a cocktail solution containing all three kinds of protein at the appropriate concentration was made to act as the $N$. caninum detector.

A sample group, comprising 12 positive sera and 20 negative sera, was employed to evaluate the detector. The positive and negative control samples used for optimization of the protein concentration were also included among the 32 serum samples. By immobilization of MBP-NcGRA2, MBP-NcSRS2, NcSAG1, separately, or the protein cocktail, ELISAs were carried out and the PP value for each sample was calculated. The sensitivity and specificity of the assay were calculated according to the diagnostic results. 


\section{Application of diagnostic assay to serum samples from dairy cattle}

Seventy-two serum samples from cattle, collected from dairy farms in the Shizuoka Prefecture of Japan, were also tested with both the method developed in this study and a commercial iscom ELISA kit for the diagnosis of $N$. caninum. The PP values were calculated for each samples with both methods and compared by plotting the values.

\section{Additional file}

Additional file 1: Percent positivity values of field serum samples.

\section{Competing interests}

The authors declare that they have no competing interests.

\section{Authors' contributions}

JD carried out the expression and purification of MBP-NCGRA2, MBP-NCSRS2, and the immunoassays, conceived of the study, participated in its design and drafted the manuscript. TO carried out the expression and purification of NCSAG1 and immunoassays. TK participated in the design of the study. EYP conceived of the study, participated in its design, and drafted the manuscript. All authors read and approved the final manuscript.

\section{Acknowledgements}

This work was partly supported by Grant-in-Aid for Scientific Research (A) Grant No.22248009 from the Ministry of Education, Culture, Sports, Science and Technology. We thank Mr. Junichi Noda of Shizuoka Prefecture Tobu Livestock Disease Diagnostic Center for providing cattle serum samples.

Received: 31 December 2011 Accepted: 29 March 2012

Published: 4 May 2012

\section{References}

1. Bjerkas I, Mohn SF, Presthus J: Unidentified cyst-forming sporozoon causing encephalomyelitis and myositis in dogs. Z Parasitenkd 1984 70(2):271-274

2. Buxton D, Maley SW, Thomson KM, Trees AJ, Innes EA: Experimental infection of non-pregnant and pregnant sheep with Neospora caninum. J Comp Pathol 1997, 117(1):1-16.

3. Dubey JP, Hartley WJ, Lindsay DS, Topper MJ: Fatal congenital Neospora caninum infection in a lamb. J Parasitol 1990, 76(1):127-130.

4. Lindsay DS, Rippey NS, Powe TA, Sartin EA, Dubey JP, Blagburn BL: Abortions, fetal death, and stillbirths in pregnant pygmy goats inoculated with tachyzoites of Neospora caninum. Am J Vet Res 1995, 56(9):1176-1180.

5. Dubey JP, Dorough KR, Jenkins MC, Liddell S, Speer CA, Kwok OC, Shen SK: Canine neosporosis: clinical signs, diagnosis, treatment and isolation of Neospora caninum in mice and cell culture. Int J Parasitol 1998, 28(8):1293-1304.

6. Dubey JP, Schares G, Ortega-Mora LM: Epidemiology and control of neosporosis and Neospora caninum. Clin Microbiol Rev 2007, 20(2): 323-367.

7. Davison HC, Otter A, Trees AJ: Estimation of vertical and horizontal transmission parameters of Neospora caninum infections in dairy cattle. Int J Parasitol 1999, 29(10):1683-1689.

8. Campero CM, Anderson ML, Conosciuto G, Odriozola H, Bretschneider G, Poso MA: Neospora caninum-associated abortion in a dairy herd in Argentina. Vet Rec 1998, 143(8):228-229.

9. Carruthers VB, Sibley LD: Sequential protein secretion from three distinct organelles of Toxoplasma gondii accompanies invasion of human fibroblasts. Eur J Cell Biol 1997, 73(2):114-123.

10. Cesbron-Delauw MF, Lecordier L, Mercier C: Role of secretory dense granule organelles in the pathogenesis of toxoplasmosis. Curr Top Microbiol Immunol 1996, 219:59-65.
11. Debache K, Guionaud C, Alaeddine F, Mevissen M, Hemphill A: Vaccination of mice with recombinant NcROP2 antigen reduces mortality and cerebral infection in mice infected with Neospora caninum tachyzoites. Int J Parasitol 2008, 38(12):1455-1463.

12. Howe DK, Crawford AC, Lindsay D, Sibley LD: The p29 and p35 immunodominant antigens of neospora caninum tachyzoites are homologous to the family of surface antigens of toxoplasma gondii. Infect Immun 1998, 66(11):5322-5328.

13. Venturini MC, Venturini L, Bacigalupe D, Machuca M, Echaide I, Basso W, Unzaga JM, Di Lorenzo C, Guglielmone A, Jenkins MC, et al: Neospora caninum infections in bovine foetuses and dairy cows with abortions in Argentina. Int J Parasitol 1999, 29(10):1705-1708

14. Atkinson R, Harper PA, Reichel MP, Ellis JT: Progress in the serodiagnosis of Neospora caninum infections of cattle. Parasitol Today 2000, 16(3): 110-114.

15. Packham AE, Sverlow KW, Conrad PA, Loomis EF, Rowe JD, Anderson ML, Marsh AE, Cray C, Barr BC: A modified agglutination test for Neospora caninum: development, optimization, and comparison to the indirect fluorescent-antibody test and enzyme-linked immunosorbent assay. Clin Diagn Lab Immunol 1998, 5(4):467-473.

16. Baszler TV, Knowles DP, Dubey JP, Gay JM, Mathison BA, McElwain TF: Serological diagnosis of bovine neosporosis by Neospora caninum monoclonal antibody-based competitive inhibition enzyme-linked immunosorbent assay. J Clin Microbiol 1996, 34(6):1423-1428.

17. Bjorkman C, Naslund K, Stenlund S, Maley SW, Buxton D, Uggla A: An IgG avidity ELISA to discriminate between recent and chronic Neospora caninum infection. J Vet Diagn Invest 1999, 11(1):41-44.

18. Osawa T, Wastling J, Maley S, Buxton D, Innes EA: A multiple antigen ELISA to detect Neospora-specific antibodies in bovine sera, bovine foetal fluids, ovine and caprine sera. Vet Parasitol 1998, 79(1):19-34

19. Nishikawa $Y$, Xuan $X$, Nagasawa $H$, Igarashi I, Fujisaki $K$, Otsuka H, Mikami T: Prevention of vertical transmission of Neospora caninum in BALB/c mice by recombinant vaccinia virus carrying NcSRS2 gene. Vaccine 2001, 19 $(13-14): 1710-1716$

20. Cannas A, Naguleswaran A, Muller N, Eperon S, Gottstein B, Hemphill A: Vaccination of mice against experimental Neospora caninum infection using NcSAG1- and NcSRS2-based recombinant antigens and DNA vaccines. Parasitology 2003, 126(Pt 4):303-312.

21. Cannas A, Naguleswaran A, Muller N, Gottstein B, Hemphill A: Reduced cerebral infection of Neospora caninum-infected mice after vaccination with recombinant microneme protein $\mathrm{NcMIC3}$ and ribi adjuvant. J Parasitol 2003, 89(1):44-50.

22. Alaeddine F, Keller N, Leepin A, Hemphill A: Reduced infection and protection from clinical signs of cerebral neosporosis in C57BL/6 mice vaccinated with recombinant microneme antigen NcMIC1. J Parasitol 2005, 91(3):657-665.

23. Jenkins M, Parker C, Tuo W, Vinyard B, Dubey JP: Inclusion of CpG adjuvant with plasmid DNA coding for NcGRA7 improves protection against congenital neosporosis. Infect Immun 2004, 72(3):1817-1819.

24. Nishikawa Y, Claveria FG, Fujisaki K, Nagasawa H: Studies on serological cross-reaction of Neospora caninum with Toxoplasma gondii and Hammondia heydorni. J Vet Med Sci 2002, 64(2):161-164

25. Arnold FH: Metal-affinity separations: a new dimension in protein processing. Biotechnology (N Y) 1991, 9(2):151-156

26. Edwards AM, Arrowsmith $\mathrm{CH}$, Christendat D, Dharamsi A, Friesen JD, Greenblatt JF, Vedadi M: Protein production: feeding the crystallographers and NMR spectroscopists. Nat Struct Biol 2000, 7(Suppl):970-972.

27. Debache K, Alaeddine F, Guionaud C, Monney T, Muller J, Strohbusch M, Leib SL, Grandgirard D, Hemphill A: Vaccination with recombinant NcROP2 combined with recombinant NcMIC1 and NcMIC3 reduces cerebral infection and vertical transmission in mice experimentally infected with Neospora caninum tachyzoites. Int J Parasitol 2009, 39 (12):1373-1384.

28. Kapust RB, Waugh DS: Escherichia coli maltose-binding protein is uncommonly effective at promoting the solubility of polypeptides to which it is fused. Protein Sci 1999, 8(8):1668-1674.

29. Park EY, Abe T, Kato T: Improved expression of fusion protein using a cysteine- protease- and chitinase-deficient Bombyx mori (silkworm) multiple nucleopolyhedrovirus bacmid in silkworm larvae. Biotechnol Appl Biochem 2008, 49(Pt 2):135-140. 
30. Barr BC, Anderson ML, Woods LW, Dubey JP, Conrad PA: Neospora-like protozoal infections associated with abortion in goats. J Vet Diagn Invest 1992, 4(3):365-367.

31. Dubey JP, Porterfield ML: Neospora caninum (Apicomplexa) in an aborted equine fetus. J Parasitol 1990, 76(5):732-734.

32. Lindsay DS, Steinberg H, Dubielzig RR, Semrad SD, Konkle DM, Miller PE, Blagburn BL: Central nervous system neosporosis in a foal. $J$ Vet Diagn Invest 1996, 8(4):507-510

33. Laemmli UK: Cleavage of structural proteins during the assembly of the head of bacteriophage T4. Nature 1970, 227(5259):680-685.

doi:10.1186/1472-6750-12-19

Cite this article as: Dong et al:: Development of a diagnostic method for neosporosis in cattle using recombinant Neospora caninum proteins. BMC Biotechnology 2012 12:19.

\section{Submit your next manuscript to BioMed Central and take full advantage of:}

- Convenient online submission

- Thorough peer review

- No space constraints or color figure charges

- Immediate publication on acceptance

- Inclusion in PubMed, CAS, Scopus and Google Scholar

- Research which is freely available for redistribution 